\title{
Necrotic Uveal Melanoma
}

National Cancer Institute

\section{Source}

National Cancer Institute. Necrotic Uveal Melanoma. NCI Thesaurus. Code C7990.

A uveal melanoma characterized by the presence of tumor cell necrosis. 